\title{
HETIIDI IMPEERIUMI JA ASSÜÜRIA SUURRIIGI SUHTED U 1365-1180 EKR
}

\author{
Vladimir Sazonov
}

Hetiidi impeeriumi ja Assüüria suhetele 14.-13. sajandil $\mathrm{eKr}^{1}$ pole erialakirjanduses seni piisavalt tähelepanu pööratud. Uurijate jaoks on nende suhete rekonstrueerimine üsnagi keeruline ja tülikas ülesanne, kuna sellest ajast on säilinud vähe ja vaid fragmentaarseid allikaid. Seega on taoliste suhete uurimine nagu mosaiigi kokkupanemine killukestest, millest valdav osa on puudu.

Siiski on mõningaid uurimusi sellele teemale pühendatud, sh ka väga mainekaid ja teedrajavaid. Siinkohal tuleks kindlasti mainida ühte viimast uurimust sellest valdkonnast - vene assürioloogi ja hetitoloogi A. A. Nemirovski sulest 2008. aastal ilmunud artiklit. ${ }^{2}$ Hetiidi-assüüria suhete

\footnotetext{
Käesolev artikkel valmis Eesti Teadusfondi grantide 8669 ja 8993 toetusel.

1 Muistse Lähis-Ida jaoks kasutatakse pikka, keskmist ja lühikest kronoloogiate süsteemi. Käesoleva artikli autor eelistab kasutada keskmist kronoloogiat. Üks võtmesündmus, mille järgi Mesopotaamia ja Anatoolia ajalugu dateeritakse, on Babüloni linna vallutamine Hetiidi kuninga Muršili I poolt. Näiteks Gary Beckman toob oma artiklis ära mitu kronoloogiate süsteemi, mille kohaselt Babüloni vallutamine lühikese kronoloogia järgi leidis aset 1522+9 (1531.) a, keskmise kronoloogia kohaselt 1586+9 (1595.) a ja pika järgi 1642+9 (1651.) a eKr, vt Gary Beckman, "Hittite chronology", Akkadica, 119-120 (2000), 28. Veel on käibel kronoloogia, mille pakkusid välja H. Gashe jt ja mille kohaselt Babüloni vallutamine leidis aset $1490+9$ (1499.), 1531. a või 1595. a eKr (H. Gashe, J. A. Armstrong, S. W. Cole, V. G. Gurzadyan, Dating of fall of Babylon: a reappraisal of second-millennium chronology (Chicago, IL: University of Ghent and the Oriental Institute of the University of Chicago, 1998). Seega leidis sündmus aset ajavahemikus 1651-149o eKr. Küsimusele, milline kronoloogiatest on õige, pole hetkel võimalik vastata. Kronoloogiate kohta vt veel nt Leonhard Sassmannshausen, "Babylonian chronology of the 2 nd half of the 2 nd millennium B.C.", Mesopotamian dark age revisited, Proceedings of an international conference of SCIEM 2000, Vienna 8th-9th November 2002, ed. by Hermann Hunger and Regine Pruzsinszky (Wien: Österreichische Akademie der Wissenschaften, 2004), 61-70; Regine Pruzsinszky, "Evidence for the short chronology in Mesopotamia: the chronological relationship between the texts from Emar and Ekalte", ibid., 43-50; Oliver Rouault, "Chronological problems concerning the Middle Euphrates during the Bronze Age", ibid., 51-59; James Mellart, "Anatolian chronology in the Early and Middle Bronze Age", Anatolian Studies, VII (1957), 55-88.

2 Vt nt Aleksandr A. Nemirovskiü, "K istorii khetto-assiriǔskikh otnosheniǐ v kontse XIII - nachale XII v. do n.é.”, Vestnik Drevneŭ Istorii, 2 (2008), 3-24.
} 
küsimustega tegeleb ka Moskva Riikliku Ülikooli õppejõud B. E. Aleksandrov. ${ }^{3}$ Mainimisväärsed on samuti mõned varasemad selle teemaga seotud uurimused, nagu näiteks Hannes D. Galteri ${ }^{4}$, Heinrich Otteni ${ }^{5}$, ja J. D. Hawkinsi kirjutised ${ }^{6}$. Järgnevalt aga üritan välja pakkuda omapoolse visiooni võimalikest Hetiidi-Assüüria suhetest. Samas tahaks kohe ära märkida, et antud artiklis ei tule vaatluse alla hurriidi-Assüüria ja hurriidiHetiidi suhteid, ning samuti Egiptuse-Hetiidi korrespondents, ${ }^{7}$ kuna see suurendaks tunduvalt artikli mahtu ning poleks minu arvates otstarbekas.

\section{Hetiidi impeerium rahvusvahelisel areenil ja Mitanni küsimus}

Hetiidi kuningriik astus suurriigina rahvusvahelistesse suhetesse tunduvalt varem kui Assüüria - juba 17. sajandil eKr. ${ }^{8}$ Selle võimuga arvestati Babüloonias, Anatoolias, Põhja-Mesopotaamias, Süürias, Palestiinas ja Kaukaasias. See oli aeg, mil kuningas Hattušili I (1650-20 eKr), Hetiidi kuningriigi rajaja, vallutas valdava enamiku Anatoolia platoost ja Põhja-Süüria alad ning saavutas kontrolli peaaegu terve tänapäeva Türgi ja ligi poole Süüria riigi territooriumi üle. Põhjas jõudsid hetiidid Musta mereni, lõunas aga Vahemereni, saades kontrolli alla isegi Küprose. Järgmine kuningas Muršili I ${ }^{9}(1620-1590 \mathrm{eKr})$ läks veel kaugemale - ta jätkas vallutusi Süürias ning

\footnotetext{
3 Tänan Boris Aleksandrovit antud materjalide ning kasulike märkuste ja soovituste eest. Aleksandrovi uurimistöödest Assüüria ja Hetiidi kuningriikide ajaloost vt nt "Ideologiya "velikotsarstvennosti" v Anatolii pozdnebronzovogo veka", Tret'ya mezhdunarodnaya konferentsiya "Ierarkhiya i vlast'v istorii tsivilizatsiu. II. Stat'i doklady = Third International Conference "Hierarchy and Power in the History of Civilizations", II. Selected Papers, ed. by Dmitri M. Bondarenko, Alekxandre A. Nemirovskiy (Moscow, 2007), 15-27; A. A. Nemirovskil̆, B. E. Aleksandrov, Na Solntse, otsa moego, ya polagayus', IBot I 34 i istoriya Verkhneı̆ Mesopotamii v XIII v do n.é. (Moskva: Rossiǔskaya Akademiya Nauk, Institut vseobshcheǐ istorii, Tsentr sravnitel'nogo izucheniya drevnikh tsivilizatsiǔ, 2007).

4 Hannes D. Galter, "28.80o Hethiter”, Journal of Cuneiform Studies, 40:2 (1988), 217-235.

5 Heinrich Otten, "Korrespondenz mit Tukulti-Ninurta I. aus Boğazköy”, Die Inschriften Tukulti-Ninurtas I. und seiner Nachfolger, hrsg. von Ernst F. Weidnen, Archiv für Orientforschung, Beiheft 12 (Graz, 1959), 64-75.

6 J. D. Hawkins, "Assyrians and Hittites", Iraq, 36 (1974), 67-83.

7 Vt lähemalt Elmar Edel, Die ägyptisch-hethitische Korrespondenz aus Boghazköy in babylonischer und hethitischer Sprache, I, Umschrift und Übersetzungen, Abhandlungen der Rheinisch-Westfälischen Akademie der Wissenschaften, 77 (Westdeutscher Verlag, 1994).

8 Vana Kuningriigi ajaloo kohta vt Oğuz Soysal, "Beiträge zur althethitischen Geschichte (III): kleine Fragmente historischen Inhalts", Zeitschrift für Assyriologie und Vorderasiatische Geschichte, 95, hrsg. von Walther Sallaberger in Verbindung mit A. Cavineaux, U. Seidl, G. Wilhelm (Berlin: Walter de Gruyter, 2005), 121-144.

9 Muršili I kohta vt Horst Klengel, Geschichte des Hethitischen Reiches, Handbuch der Orientalistik $=$ Handbook of Oriental Studies, I: Der Nahe und Mittlere Osten $=$ The Near and Middle East (Leiden: Brill, 1999), 59-67.
} 
seejärel marssis oma võiduka armeega $2000 \mathrm{~km}$ lõunasse läbi tänapäevase Türgi, Süüria ja Iraagi ning vallutas Vana-Babüloonia suurriigi, kukutades seal 1595. aastal eKr (keskmise kronoloogia järgi) viimase kuninga Hammurapi dünastiast - Samsuditana. ${ }^{10}$

Aga mis toimus Hetiidi riigis pärast 1590. aastat eKr? Nagu me teame, leidis seal 159o. aastal aset riigipööre: Muršili I sai surma, Hetiidi riik käis alla ning oli ebastabiilne koguni 15. sajandi keskpaigani, mil Tuthalija II ${ }^{11}$ (15. sajandi II poolel) suutis kuningriigi võimsuse taastada. Kuid alles Šuppiluliuma I ${ }^{12}(1380-40)$, kes vallutas Põhja-Süüria, tegi Hetiidi kuningriigist tõelise impeeriumi. Hetiidi impeerium püsis suurriikide seas kogu 13. sajandi vältel, kuid u 1220. aastate lõpust algas taas langus ning u 1190-80 varises riik mererahvaste invasiooni ja sisemise ebastabiilsuse tõttu lõplikult kokku.

15. sajandiks eKr kujunes välja selline rahvusvaheline süsteem, kus eksisteerisid järgmised suurriigid: Egiptus, Mitanni ${ }^{13}$, kassiitide Babüloonia ja Hetiidi impeerium. 14. sajandi keskel suutis Šuppiluliuma I Mitanni kuningriiki nõrgestada, nii et purustatud ja peaaegu hävitatud Mitannis otsiti võimalust liidu loomiseks teiste riikidega. Kuna kassiidi Babüloonia oli pigem hetiidisõbralik, siis pöörasid hurriidid oma tähelepanu uuele tõusvale võimule, milleks oli Assüüria.

Kuningas Šuppiluliuma I õnneks muutus Egiptus 14. sajandi keskpaigaks passiivseks. Sõjalised ambitsioonid ja vallutused olid unustatud ning suure vallutaja Thutmosis III $^{14}$ ja tema järeltulijate aeg oli möödas. Egiptuses tuli võimule välispoliitilisel tasandil passiivne Amenhotep IV ${ }^{15}$ kes viis läbi oma tuntud Atoni monoteistliku reformi, ehitas uue "päikselise linna" ja see hõivas kogu ta aja - vallutused teda väga ei huvitanud. Mitanni oli

\footnotetext{
10 Vt Peeter Espak, Vladimir Sazonov, "Võimuvõitlus muistses Lähis-Idas”, Horisont, 4 (2007), 39; Babüloni vallutamise ja Lähis-Ida kronoloogia kohta II at eKr vt D. N. Gromova, "Bitva s trëkhgolovȳm drakonom: novȳĭ peresmotr datirovok vzyatiya Vavilona i Khalapa voǐskami Mursili I i voprosȳ peredneaziatskoŭ khronologii II tȳs. do n.é.", Vestnik Drevneŭ Istorii, 4 (2009), 104-123. Siinkohal tuleks märkida, et Gary Backmani sõnul on see sündmus (1595) üks kahest teadaolevast sünkronismist Hetiidi riigi ja Mesopotaamia vahel, vt Beckman, "Hittite chronology", 23-24.

11 Tuthalija II kohta vt Klengel, Geschichte des Hethitischen Reiches, 127-134.

12 Vt ibid., 135-168; Šuppiluliuma I kohta vt Hans Gustav Güterbock, "The deeds of Suppiluliuma as told by his son, Mursili II", Journal of Cuneiform Studies, 10 (1956), 107-130.

13 Mitanni riigi lõid hurriidid. Selle teine nimetus oli Hanigalbat.

14 Thutmosis III kohta vt Sergei Stadnikov, Vana-Egiptuse kultuurilugu: valitud artikleid, tõlkeid ja esseid (Tallinn: Kodutrükk, 1998), 265-276.

15 Amenhotep IV kohta vt Tarmo Kulmar, "Vaarao Amenhotep IV (Ehnatoni) riigivalitsemisviisi võimalikust eripärast”, Mäetagused, 42 (2009), 111-122; E. Hornung, Echnaton: die Religion des Lichtes (Düsseldorf: Patmos Verlag, 2005).
} 
lõpuks võidetud, Põhja-Süüria linnriigid vallutatud, enamik Anatoolia aladest samuti. Babülooniaga olid hetiitidel tollal enamasti sõbralikud suhted. Kuid samas oli tõusev Aššuri linnriik muutumas Assüüria kuningriigiks, andes Hetiidi kuningale põhjust muretsemiseks. Kuna tark ja ettenägelik Šuppiluliuma I mõistis, et Assüüriast võib saada ohtlik rivaal, toetas ta nõrgestatud Mitanni kuningriigi troonil prints Šattivasat, et teda hiljem kontrollida, kuna Šuppiluliuma I kartis Mitanni võimalikku liitu Assüüriaga. Kui see oleks juhtunud, siis oleks see võinud kaasa tuua hetiitide tõrjumise Eufrati jõe taha. Strateegilises ja geopoliitilises mõttes tähendanuks see suurt kaotust, sest siis oleks Hetiidi võimu alla jäänud vaid Sise-Anatoolia alad. Šuppiluliuma I aga tahtis kontrollida Eufrati ülemjooksu. Selle eesmärgiga üritaski ta tugevdada oma mõju Mitanni riigile seeläbi, et andis Šattivasale naiseks oma tütre, kellele ta kohe nõudis koguni MÍ.LUGAL’i ehk "kuninga naise" staatust. ${ }^{16}$ N. B. Jankovskaja oletusel oli kuningas Šuppiluliuma I tütre positsioon Mitannis nähtavasti väga kõrge ning jäi selliseks ka pärast tema abikaasa kuningas Šattivasa surma. Seega oli ta oma positsioonilt midagi sarnast koguni Hetiidi peakuningannaga - tavanannaga. ${ }^{17}$

Šuppiluliuma I ise oli abiellunud kassiidi päritolu Babüloonia kuninga Burna-Buriaš II tütrega, soovides ilmselt olla ka dünastilises liidus kassiitidega, kes valitsesid Babüloonias pärast 1595. aastat eKr. Šuppiluliuma I tegi oma naisest tavananna, see tähendab "peakuninganna". ${ }^{18}$ Liit ja sõprus võimsa Babülooniaga olid Šuppiluliumale vajalikud, eriti olukorras, mil Aššuri linnriik hakkas järsult ekspansionistlikku poliitikat läbi viima. Ka Babülooniale ei meeldinud Aššuri - endise vasall-riigi - kiire tõus ja vabanemine Babüloonia mõjust. Pole kahtlust, et kõik need dünastilised abielud olid Šuppiluliuma I ning tema impeeriumi jaoks kasulikud. Ilmselge oli see, et võimas Šuppiluliuma kartis Assüüria tõusu, mis polnud veel oma täisvõimsust saavutanud, aga kus kaval, auahne ja nutikas kuningas Aššuruballit I hakkas võimu koondama ja tegi kõik, et teha Assüüriast tulevikus võimas suurriik.

Pärast Šuppiluliuma I surma tekkisid tema järeltulijatel, eriti kuningas Muvatalli II-l pinged Egiptusega, mis selleks ajaks oli toibunud välispoliitilisest passiivsusest ning kus oli võimule tulnud uus auahne ja sõjakas XIX

16 Ninel’ B. Yankovskaya, “Arrapkha - ubezhishche Shattivasȳ, sȳna Tushrattȳ: novȳe materialȳ k épizody iz mitanniǐskoŭ istorii”, Vestnik Drevne Istorii, 1 (1979), 25.

17 Ibid., 25.

18 Tavananna kohta vt S. R. Bin-Nun, The Tawananna in the Hittite kingdom, Texte der Hethiter, hrsg. von A. Kammenhuber, H. 5 (Heidelberg: Carl Winter Universitätsverlag, 1975). 
dünastia. ${ }^{19}$ Ambitsioonikad ja agressiivsed vaaraod Seti I ja eriti Ramses II ${ }^{20}$ üritasid taastada oma kontrolli Palestiina ja Süüria üle ning taastada Egiptuse võimsust ja prestiiži, mis 14. sajandi teisel poolel oli Amenhotep IV ja tema järglaste reformide tõttu tunduvalt hääbunud. ${ }^{21}$ Ning teatud hetkel põrkusid egiptlaste ja hetiitide huvid. Egiptlased soovisid saada tagasi alad Palestiinas ja Süürias, kuid osa neist territooriumitest olid selleks hetkeks juba hetiitide mõjusfääris ning konflikt kulmineerus Kadeši lahingus ligikaudu aastatel 1286/85 eKr. ${ }^{22}$

Ilmselt tuli ka see, et Mitanni oli nüüd nõrk, võimetu ja hetiitide mõju all ning et Hetiidi impeerium ja Egiptus omavahel sõdisid, kasuks tõusvale Assüüriale, kus alguses oli võimul sõjakas Adadnarari I ja seejärel tema veelgi sõjakam poeg Salmanassar I. Salmanassar vallutas lõplikult hurriitide alad - Hanigalbati, Põhja-Mesopotaamias asuvad Nairi rahvad ja veel paljud territooriumid. Just tema valitsemisaja alguses otsustasid Hetiidi impeerium ja Egiptus sõlmida omavahel rahulepingu ning lausa liidu. ${ }^{23}$ Tõenäoliselt sundis neid seda tegema ka asjaolu, et nüüd polnud Hetiidi impeeriumi naabriks enam Mitanni (ehk Hanigalbat), vaid hoopis tugev Kesk-Assüüria riik ja et kunagi võimas Babüloonia hakkas viimasel ajal assüürlastelt lüüa saama. Assüürlased hakkasid pilke heitma ka Elami poole.

Assüüria kiire tõus sundis hetiite ja egiptlasi sõjategevust peatama ning hakkama mõtlema koostöö peale. Sõlmitigi leping hetiidi kuninga Hattušili III ja Ramses II vahel. ${ }^{24}$ Tähtis on hetiidi ajaloo dateerimise seisukohast see, et leping sõlmiti Ramses II 21. valitsemisaastal. ${ }^{25}$ Ramses II tuli võimule pika kronoloogia järgi 1304., keskmise järgi 1290. ja lühikese järgi 1279. aastal. Kuna me teame, et Ramses II valitses 67 aastat, siis võisid tema võimuloleku aastad olla vastavalt kronoloogiatele kas 1304-1237, 1290-24 või siis 1279-13. ${ }^{26}$

\footnotetext{
19 Egiptuse vaarao ja Muvatalli II vastasseisust vt Klengel, Geschichte des Hethitischen Reiches, 214-218.

20 Ramses II kohta vt Bernadett Menyu, Ramses II: tsar' tsare (Moskva: AST-Astrel', 2006).

21 Trevor Bryce, The kingdom of the Hittites (Oxford University Press, 2005), 227-230.

22 Oliver R. Garni, Khettỹ: razryshiteli Vavilona (Moskva: Tsentrpoligraf, 2002), 51; Bryce'i järgi leidis Kadeši lahing aset hoopis 1274. aastal, vt Bryce, The kingdom of the Hittites, 234-241.

23 Mezhdugosudarstvennȳe otnosheniya i diplomatiya na Drevnem Vostoke, otvetstv. red. I. A. Stuchevskiǔ (Moskva: Nauka, 1987), 79-87.

24 Menyu, Ramses II, 96-98; vt lepingut Ramses II ja Hattušili III vahel Gary Beckman, Hittite diplomatic texts, Writings from the Ancient World Series, second edition (Atlanta, GA: Scholars Press, 1999), 96-100; vt ka M. B. Rowton, "The background of the treaty between Ramesses II and Hattušiliš III", Journal of Cuneiform Studies, 13:1 (1959), 1-11. 25 Rowton, "The background of the treaty between Ramesses II and Hattušiliš III", 1.

26 Vt A. A. Nemirovskiŭ, "Pis'mo Khattusilisa III Kadashman-Éllilyu (KBO I 10) i voprosȳ blizhnevostochnoı̆ khronologii”, Vestnik Drevne Istorii, 3 (2007); Nemirovskiı̆,
} 
Ramses II valitsusaja alguses toimus Kadeši lahing (1280. või 1270. aastatel) ning Hetiidi kuningas, kellega ta võitles, oli Muvatalli (valitses keskmise kronoloogia järgi u 1306-1282 või lühikese järgi u 1295-72), aga oma lepingu sõlmimise ajal (pika kronoloogia järgi 1283., keskmise järgi 1269. või lühikese järgi 1259/58. aastal) oli Hetiidi kuningaks juba Hattušili III (valitses keskmise kronoloogia järgi 1275-50, lühikese järgi 1267-37). On teada, et Hattušili III tuli võimule pärast oma vennapoega Urhi-Tešupi, ${ }^{27}$ kes valitses $6-7$ aastat ja kes oli oma onu Hattušili III poolt kukutatud keskmise kronoloogia järgi u 1276/75. aastal. Seega, Hattušili III võis keskmise kronoloogia järgi asuda troonile u 1275, aga võimalik, et ka natuke varem või hiljem. Samas pole ka lühikene ja pikk kronoloogia välistatud ja Hattušili III võis saada kuningaks juba 1280. aastatel või siis hoopis 1267. aasta paiku.

\section{Aššuruballit I ja Assüüria tulek rahvusvahelisele areenile}

Assüüria ehk Aššuri linnrriik ei saanud 17.-14. sajandil eKr uhkustada sellise edukuse ja impeeriumi loomisega, nagu seda tegid hetiidid juba 17. sajandil. Aššur oli pikka aega Akkadi (24--22. sajandil), seejärel Ur III (2112-2004) suurriikide koosseisus ja siis iseseisev ning pooliseseisev riik (21. sajandi lõpust 14. sajandi keskpaigani), sõltudes kas Babülooniast või Mitannist. Aššur oli seega vaid suhteliselt tähtsusetu linnriik Põhja-Mesopotaamias nagu paljudki teised tolle aja linnriigid, v.a Šamši-Adad I ajastul (1813-1781), kes lõi Põhja-Mesopotaamias oma suurriigi ja kontrollis mh ka Aššurit. Kuigi peame kohe mainima, et Šamši-Adad polnud assüürlane, vaid hoopis lääne-semiidi päritolu ammoriit. ${ }^{28}$ Kuid assüürlased pidasid teda hiljem oma kuningaks ja võtsid palju, sh mitmed ideoloogilised innovatsioonid, suurriigi idee jne, just temalt üle.

Aššuri linnriigist alguse saanud Assüüria muutus 14. sajandi lõpuks juba päris tugevaks kuningriigiks. Eelkõige oli see tingitud linnriigi alates 20. sajandist järkuvalt kasvanud majanduslikust jõukusest, kuid võlgnes tänu ka auahnele valitsejale Aššuruballit I-le (valitses keskmise kronoloogia

Aleksandrov, Na Solntse, otsa moego, ya polagayus', 7, 8.

27 Vt "Hattusilis III: Apologia Pro Vita Sua", tlk Jaan Puhvel, Muinasaja kirjanduse antoloogia, koost Amar Annus (Varrak, 2005), 211-214; vt ka Werner Wouters, "UrhiTešub and Ramses-Letters from Boghazköy”, Journal of Cuneiform Studies, 41:2 (1989), 226-234.

28 Šamši-Adad I kohta vt Mogens Trolle Larsen, "The city and its king: on the Old Assyrian notion of kingship", Le palais et la royauté (archéologie et civilisation), ed. by Paul Garelli, XIX ${ }^{e}$ Recontre Assyriologique Internationale, organisée par le groupe François Thureau-Dangin, Paris, 29 juin - 2 juillet 1971 (Paris: Librairie Orientaliste Paul Geuthner, 1974), 286. 
järgi 1366/65-1331/30), kes oli esimene tõeline Assüüria kuningas; ta oli võimuahne ja edukas oma välispoliitikas. Aššuruballit I hakkas suhtlema Egiptuse vaaraoga nagu võrdne võrdsega, nimetades vaaraod vennaks, ennast aga esimesena Aššuri valitsejatest "kuningaks" (̌̌arru), kuigi seda mitte ametlikes raidkirjades, vaid üksnes kirjavahetuses. ${ }^{29}$ Näiteks on Tell el-Amarna arhiivist Egiptuses leitud akkadikeelne kiri (EA $16^{30}$ ), mille saatis Assüüria kuningas Aššuruballit I Egiptuse vaaraole Amenhotep IV-le (Ehnaton), kus Egiptuse vaaraod nimetatakse LUGAL GAL LUGAL ${ }^{\mathrm{KUR}} M i$-is-sa-ri ŠEŠ-ia - "suurkuningas, Egiptuse kuningas, minu vend ${ }^{\text {“31 }}$ ning Aššuruballit I ise nimetas ennast selles kirjas "Assüüria kuningas, suurkuningas, sinu vend". ${ }^{2}$ Seega oli või vähemalt üritas Assüüria kuningas olla võrdväärne Hetiidi impeeriumi valitsejate, Egiptuse vaaraode ja Babüloonia suurkuningatega. ${ }^{33}$

See suurkuninglik tiitel LUGAL GAL (akkadi šarru rabû ja hetiidi šalliš haššsus) oli kasutusel Mesopotaamias ja Anatoolias kuningate tähistamisel, kelle võim oli tunduvalt suurem kui linnriigi valitsejal ning seda tiitlit võis kasutada vaid tunnustatud valitseja, kuningas, kelle alluvuses olid teised kuningad, vürstid ja linnriigid. Hetiitide puhul, nagu õigesti märkis oma artiklis B. E. Aleksandrov, esineb see tiitel hetiidi kuninga Anitta tekstis, ehk siis Vana-Babüloonia ajal. ${ }^{34}$ Aleksandrov pakub välja kaks võimalikku seletust tiitli päritolu kohta: hetiidid ise leiutasid suurkuninga tiitli ning see kandus ka muistsete Idamaade teistesse kultuuridesse või nad ise laenasid nii tiitli kui "suurkuninglikkuse" ideoloogia oma naabritelt. ${ }^{35}$

29 Vt nt Pinhas Artzi, The rise of the Middle-Assyrian kingdom according to El-Amarna letters 15 16 : a contribution to the diplomatic history of Ancient Near East in the midsecond millennium B.C.E., ed. by Pinhas Artzi, Bar-Ilan studies in history (Ramat-Gan, Israel: Bar-Ilan University Press, 1978), 27, kiri nr 15, rida 3.

30 William L. Moran, The Amarna letters (Baltimore: Johns Hopkins University Press, 1992), 38-41.

31 Ibid.

32 Vt lähemalt Betina I. Faist, Der Fernhandel des assyrischen Reiches zwischen dem 14. und 11. Jh. v. Chr, Alter Orient und Altes Testament, Bd. 265, hrsg. von M. Dietrich, O. Loretz (Münster: Ugarit-Verlag, 2001), kiri EA 16, 11.

33 Assüüria suurkuninglikkuse ja suurkuninga titulatuuri kohta vt Vladimir Sazonov, Die Königstitel und -epitheta in Assyrien, im Hethiterreich und in Nordsyrien (Ugarit, Emar, Karkemiš) in der mittelassyrischen Zeit: Strukturelle Gemeinsamkeiten, Unterschiede und gegenseitige Beeinflussung, Dissertationes Historiae Universitatis Tartuensis, 21 (Tartu: Tartu Ülikooli Kirjastus, 2010), 72-73, 77, 79, 89, 91-92, 154, 175-180, 229, 237, 215, 240, 242; Aleksandrov, "Ideologiya "velikotsarstvennosti" v Anatolii pozdnebronzovogo veka", 15-27.

34 Aleksandrov, "Ideologiya "velikotsarstvennosti" v Anatolii pozdnebronzovogo veka", 15.

35 Ibid. 
Esimese Hetiidi kuninga Anitta (valitses 18. sajandil eKr) tekstis on see tiitel täitsa olemas, kuid probleemiks on see, et Anitta tekst on meieni jõudnud tunduvalt hilisemas redaktsioonis, mistõttu see tekst võis olla parandatud vastavalt tolleaegse ideoloogia suunitlustele ja huvidele. ${ }^{36}$ Kuid juhul, kui tiitel "suurkuningas" polnud leiutatud ja oli laenatud, võis see Aleksandrovi väitel tulla Süüriast Jamhadist. ${ }^{37}$ Samal seisukohal on ka Gerd Steiner. ${ }^{38}$ See võib olla üsna tõenäoline, kuid mulle tundub, et "suurkuninga" tiitel on siiski pärit Assüüriast ja Babülooniast, ${ }^{39}$ kuna see esineb Jamhadis juba varakult, Vana-Babüloonia ajastul. ${ }^{40}$ Nõustun G. Beckmaniga, ${ }^{41}$ et Mesopotaamia mõju hetiitidele oli väga tugev ja see tiitel pärineb Mesopotaamiast, küsimus aga ongi, kas Jamhadist Süürias või siis Šamši-Adad I suurriigist, mille valitsejad esinesid diplomaatilistes kirjades ka kui "suurkuningad". 42

Läks veel sajand, enne kui Assüüria võimsus muutus nii tugevaks, et hakkas ähvardama koguni Hetiidi impeeriumi piirialasid, hävitas Hanigalbati, pani küsimärgi alla Babüloonia ja Elami poliitilise eksistentsi ning tekitas tõsiseid ebameeldivusi Egiptusele.

\section{Kuningas Adadnarari I "läänele orienteeritud poliitika" ja tema tunnustamine Hetiidi suurkuninga poolt}

14. sajandi teisel poolel ja 13. sajandi algul eKr tugevdasid Aššuruballit I, tema järglased ja eriti kuningas Adadnarari I (u 1307-1275) Assüüria riiki. Aššuri linnriik muutus kolme-nelja põlvkonnaga võimsaks impeeriumiks. Siin paistis eriti silma Adadnarari I, impeeriumi rajaja, kes oli eriti edukas vallutaja. ${ }^{43}$

\footnotetext{
36 Aleksandrov, "Ideologiya "velikotsarstvennosti" v Anatolii pozdnebronzovogo veka", 15.

37 Ibid, 17.

38 Gerd Steiner, "Was bedeutet LUGAL- $z u-n u$.... ul-tam-li im Aleppo-Vertrag", Altorientalische Forschungen, 26:1 (1999), 13-25.

39 Vt ka Vladimir Sazonov, "Tabarna/Labarna - imperiaalse idee reflektsioon ühe hetiidi kuningliku tiitli näitel”, Tuna, 2 (2011), 18-25.

40 Aleksandrov, "Ideologiya "velikotsarstvennosti" v Anatolii pozdnebronzovogo veka", 15-16.

41 Vt Gary Beckman, “"My Sun-God”: reflections of Mesopotamian conceptions of kingship among Hittites", Ideologies as intercultural phenomena, Proceedings of the Third Annual Symposium of the Assyrian and Babylonian Intellectual Heritage Project, held in Chicago, USA, October 27-31, 2000, ed. by A. Panaino et al., Melammu Symposia, 3 (Milano Universitato di Bologna, 2002), 37-43.

42 Aleksandrov, "Ideologiya "velikotsarstvennosti" v Anatolii pozdnebronzovogo veka", 17 .

43 Barbara Cifola, Analysis of variants in the Assyrian royal titulary from the origins to Tiglath-Pileser III (Napoli: Instituto Universitario Orientale, 1995), 24.
} 
Just teda võib pidada nn "lääne-poliitika" sisseviijaks Assüürias, mida hiljem rakendati Uus-Assüüria impeeriumis ka mitmeid sajandeid hiljem (9.-7. sajandil eKr). Kuid tegelikkuses rakendas juba tema esiisa Aššuruballit I sellist poliitikat üsna edukalt. See väljendus ekspansionistlikus poliitikas lääne piirkondade (Põhja-Süüria ja Põhja-Mesopotaamia alad) ja hurriidi võimu alla sattunud Hanigalbati suhtes. ${ }^{44}$ Teame, et Hanigalbat kuulus alates Šuppiluliuma I valitsemisajast (alates 14. sajandi keskpaigast) osaliselt kas hetiitide otsese või kaudse kontrolli alla. Seega tungis Adadnarari I hetiidi mõjusfääri või vähemalt lähenes sellele. Assüüria ja Hetiidi impeeriumi vahel puhvertsooniks jääva Hanigalbati hetiitide poolt vallutamata territooriumid olid nüüd muutunud "tüliõunaks" assüürlaste ja hetiitide vahel.

Adadnarari I viis läbi vallutusi hurriidi aladel Hanigalbatis ning ka teistes Süüria, Kaukaasia ja Mesopotaamia piirkondades. Arvestatavat sõjalist edu saavutas ta ka Lõuna-Mesopotaamia rindel - nimelt võitis Adadnarari I Kar-Ištari lahingus kassiit Nazimaruttašt, kes valitses tollal Babüloonias. ${ }^{45}$ Neid sündmusi kajastab "Sünkronistlik kroonika" ${ }^{46}$ Kassiidi domineerimisele Mesopotaamias tuli lõpp.

Kõik see ülalmainitud - Assüüria muutumine kuningriigiks ja seejärel impeeriumiks, imperiaalse süsteemi ning administratsiooni teke ja väljakujunemine Assüürias, propagandistlikud tekstid, kuninga isikukultuse teke, edukad vallutused ida, põhja, lääne ja lõuna suunal - tegid Assüüriast Adadnarari I valitsemise lõpuks suurriigi, mis oli oma staatuse ja võimsuse poolest võrdväärne Hetiidi impeeriumiga ja muidugi ka Egiptusega. Babüloonia oli de jure veel samuti võimsuselt võrdne, kuigi juba hakkas ilmnema selle nõrgenemine.

Hetiidi suurkuningas (ilmselt kas Urhi-Tešup ${ }^{47}$ või Hattušili III ${ }^{48}$ ) nimetas ühes oma kirjas Adadnararile (erialakirjanduses tuntud kui KUB

\footnotetext{
44 Cifola, Analysis of variants in the Assyrian royal titulary, 24.

45 Ernst F. Weidner, "Assyrische Epen über die Kassiten-Kämpfe", Arhiv für Orientforschung, 20 (1963), 113.

46 Jean-Jacques Glassner, Mesopotamian chronicles, Writings from the Ancient World, 19 (Atlanta: Society of Biblical Literature, 2004), Synchronistic Chronicle, 178 ja 179, read (A) 24'-31'.

47 Kuna Adadnarari I valitsemisajal valitsesid Hetiidi impeeriumis järjest kolm valitsejat - Muvatalli II, Urhi-Tešup ja Hattušili III -, siis on raske öelda, kes nendest valitsejatest kirjutas Adadnararile. Osa uurijaid arvab, et Hattušili III (seda toetab ka käesoleva artikli autor), kuid näiteks Gary Beckman oletab, et see oli Urhi-Tešub, vt Beckman, Hittite diplomatic texts, 24A (Letter from Urhi-Teshshup(?) of Hatti to Adad-nirari I of Assyria), 146.

48 Hattušili III kohta vt nt Heinrich Otten, Die Apologie Hattusilis III: das Bild der Überlieferung, Studien zu Boğazköy-Texten, H. 24 (Wiesbaden: Harrassowitz, 1981).
} 
XXIII 102) viimast kui šarru rabû (LUGAL.GAL) - "suurkuningas". 49 Taolist tiitlit kandis Hetiidi kuningas ise..$^{50}$ Ainult valitseja, võrdväärne teiste suurkuningatega, võis sellist tiitlit kanda. Hattušili III kirjutab samas hetiidikeelses kirjas Adadnarari I-le: “3.) [IŠs-]TU ${ }^{\text {GIŠ }}$ TUKUL-za zi-ik t[ar]-ah-ta 4.) [.]-IA-za Ras. tar-ah-ta nu-za LUGAL.GAL 5.) ki-iš-taat ...." ([Rel] vaga oled sa võitnud. Suurkuningaks oled sa saanud). ${ }^{51}$ Nüüd tunnistab juba Hetiidi suurkuningas isiklikult, et Assüüria kuningas on temaga võrdväärne, st samas staatuses olev suurkuningas. Ka Salmanassar I, Adadnarari I poeg, oli hiljem tunnistatud Hetiidi kuningate poolt "suurkuningaks". ${ }^{22}$ Barbara Cifola kirjutab tiitlist "suurkuningas", et see on kõige ilmsem argument, mis toetab tihedat sidet tiitli omastamise ja seda lubavate poliitiliste ning sõjaliste põhjenduste vahel. ${ }^{53}$ Adadnarari I oli esimene Assüüria kuningas, kes võttis kasutusele universalistlikud tiitlid ja hakkas ametlikult pretendeerima "universumi kuninga" staatusele. Neid tiitleid kasutasid enne teda vaid Babüloonia kuningad. See oli otsene väljakutse Babüloonia suurriigile ja tema kuningatele. Seda uut tiitlit - murappiš mișri u kudurri ehk "Piirimaade ja piiride laiendaja" - oli Adadnarari I raidkirjades mainitud vähemalt paar korda (nagu näiteks raidkirjas

49 Albertine Hagenbuchner, Die Korrespondenz der Hethiter, 2: Die Briefe mit Transkription, Übersetzung und Kommentar (Heidelberg: Carl Winter Universitätsverlag, 1989), 260-261, nr 192, KUB XXIII 102, read 4-5; Beckman, Hittite diplomatic texts, 24A (Letter from Urhi-Teshshup(?) of Hatti to Adad-nirari I of Assyria), 147; Cifola, Analysis of variants in the Assyrian royal titulary, 29; Amir Harrak, Assyria und Hanigalbat: a historical reconstruction of bilateral relations from the middle of the fourteenth to the end of the twelfth centuries B.C., Texte und Studien zur Orientalistik, 4 (Hildesheim: Georg Olms Verlag, 1987), 75-77.

50 Näiteks Telepinu (1525-1500) nimetas ennast kui ta-ba-ar-na ${ }^{m} T e-l e-p i-n u$ LUGAL GAL (“Tabarna Telepinu, suurkuningas”), vt Inge Hoffmann, Erla $\beta$ Telepinus (Heidelberg: Carl Winter Universitätsverlag, 1984), 12-13, rida 1; hetiidi keels kõlas LUGAL GAL kui šalli-haššu, vt Johannes Houwink ten Cate, "The Hittite usage of the concepts of 'Great Kingship', the mutual guarantee of royal succession, the personal unswerving loyalty of the vassal to his lord and the 'Chain of Command' in vassal treaties from the 13th century B.C.E.", Das geistige Erfassen der Welt im Alten Orient: Sprache, Religion, Kultur und Gesellschaft, nach Vorarbeiten von J. Hazenbos und A. Zgoll, hrsg. von C. Wilke (Wiesbaden: Harrassowitz, 2007), 192. Hattušili III kirjutab oma "Apoloogias": "Ja mina sain suurkuningaks..." - ....nu-za LUGA[(L.GAL ki-i)]š-ha-ha-at - Otten, Die Apologie Hattusilis III, 26, IV, rida 48.

51 Vt transliteratsiooni Hagenbuchner, Die Korrespondenz der Hethiter, 260-261, nr 192, KUB XXIII 102, Vs. I, read 3-5

52 Ibid., 42, $\mathrm{nr}$ 188, KBo XVIII 24, Vs. I., read 1-2: 1.) [UM-MA d UTU ${ }^{s i}$ LUGAL.] GAL ${ }^{m} A N . S I L I M-m a-n u$-sag 2.) [LUGAL.GAL LUGAL] KUR A-aš-šur ŠEŠ-In QÍ-BI-MA ("[Järgmisel viisil räägib Minu Päike,] suur[kuningas], Salmanassarile, [suurkuningale, Assü]ria maa kuningale, minu vennale, ütle!”).

53 Cifola, Analysis of variants in the Assyrian royal titulary, 29. 
A.o.76.1. $\left.{ }^{54}\right)$. Muidugi oli ta lisaks ka šar kiššati - "universumi kuningas” simat ilāni (DINGIR.MEŠ) $)^{56}$ - "Kõikide jumalate uhkus", šakkanakki/ šakanki ilāni (DINGIR.MEŠ) $)^{57}$ - "jumalate asehaldur" jne.

\section{Assü̈̈ria-Hetiidi suhete halvenemine 13. sajandil eKr}

Adadnarari I poeg Salmanassar I (1273-45 või 1269-41) oli samuti silmapaistev vallutaja, kes muuhulgas sõdis Hanigalbati ehk Mitanniga, ${ }^{58}$ hetiitide ja aramealastega, samuti uruatri hõimudega (tulevane Urartu) ${ }^{59}$ Salmanassari poeg ja järeltulija Tukultī-Ninurta I (1243-07 või 1240-05) tugevdas niigi juba võimsat Assüüriat, laiendades impeeriumi teiste riikide arvelt. Ta kontrollis suuremat osa Lähis-Idast ja vallutas lõpuks kassiitidele kuuluva Babüloonia, kusjuures kassiitide kuningas Kaštiliaš IV langes vangi. ${ }^{60}$ Babüloni linn oli vallutatud ja laastatud, jumal Marduki kuju oli assüürlaste poolt Babülonist minema viidud. ${ }^{61}$ Rahvusvaheline jõudude tasakaal Lähis-Idas oli nüüd murtud - Lähis-Ida "esimeseks viiuliks" sai Assüüria. Isegi hetiidid pidid talle osaliselt oma positsiooni loovutama.

Tukultī-Ninurta I oli tüüpiline idamaine despoot. Kuid tema õukondlastele ei meeldinud despootlik ja karm valitsemine - ta kuulutati hulluks ning hukati 1207. või 1205. aastal. Kõik Tukultī-Ninurta I vallutused olid tolleks ajaks kaotatud ning Assüüria käis umbes 100 aastaks alla. Uus tõus algas Tiglatpileser I ajal (1115-1077).

13. sajand oli aeg, mil Hetiidi impeerium ja Assüüria said naabriteks ning nende suhted hakkasid halvenema. Ilmselt toimus see Salmanassar I ajal, kuid on võimalik, et see võis toimuda ka tema isa Adadnarari I

\footnotetext{
54 Albert Kirk Grayson, Assyrian rulers of the third and second millennia BC (to 1115 BC), The Royal inscriptions of Mesopotamia, Assyrian periods, 1 (Toronto-Buffalo-London: University of Toronto Press, 1987, reprinted 2002) [edaspidi RIMA 1], A.o.76.1, 131, rida 15; vt murappiš mișri u kudurri kohta ka Walter Mayer, Politik und Kriegskunst der Assyrer, hrsg. von Manfried Dietrich, Oswald Loretz, Abhandlungen zur Literatur Alt-SyrienPalästinas und Mesopotamiens, 9 (Münster: Ugarit-Verlag, 1995), 180.

55 Cifola, Analysis of variants in the Assyrian royal titulary, 26.

56 RIMA 1, A.o.76.1, 131, rida 1.

57 Ibid., rida 2.

58 Tegelikkuses oli siin tegemist juba hurriitide kuningriigi Mitanni jäänustega, mille purustas 14. sajandil Šuppiluliuma I.

59 Salmanassar I vallutustest ja Assüüria administratsiooni loomisest Hanigalbatis vt lähemalt Harrak, Assyria und Hanigalbat, 132-205; Mayer, Politik und Kriegskunst der Assyrer, 203-205; RIMA I, A.0.77.1, 183-185.

60 Mayer, Politik und Kriegskunst der Assyrer, 214-215.

61 Ernst F. Weidner, "Studien zur Zeitgeschichte Tukulti-Ninurtas I.", Arhiv für Orientforschung, 13 (1939-41), 119.
} 
ajal. On säilinud üks kiri (KUB XXIII $102^{62}$ ), mille kirjutas ilmselt Hetiidi kuningas Muvatalli II Assüüria kuningas Adadnarari I-le:

(Vs. I 1-19) Sa jätkad rääkimist [võidust] Vašašatta ${ }^{63}$ üle ja Hurri/Mitanni maa [vallutamisest?]. Sa tegelikkuses vallutasid relvade toel. Ja sina vallutasid [...], ja said suurkuningaks. Kuid miks siiani räägid vendlusest ja Ammana mäe (ehk mägede) ${ }^{64}$ nägemisest? Mis see on, vendlus? Ja mis siis on see, Ammana mäe nägemine? Mis põhjusel peaks ma sulle kirjutama vendlusest? Kes tavaliselt kirjutab kellelegi vendluses? Kas need, kes ei ole heades suhetes, tavaliselt kirjutavad teineteisele vendlusest? Mis põhjusel ma peaksin sulle kirjutama vendlusest? Kas me oleme sinuga sündinud ühes emast? Nagu [minu vanaisa] ja mu isa ei kirjutanud Assüüria kuningale [vendlusest], sa ei peaks jätkama mulle [vendlusest], ka suurest kuninglusest kirjutamist. [See ei ole minu] soov. ${ }^{65}$

Kahjuks on ülejäänud osa kirjast praktiliselt hävinud, aga ka olemasolev lõik näitab, et Hetiidi kuningas polnud sugugi vaimustatud Adadnarari I vallutustest Hetiidi impeeriumi mõjusfääri kuuluvatel aladel ega soovinud rääkida "vendlusest" ja "sõprusest".

Gary Beckman kommenteerib seda kirja (Beckmani väljaandes nr 24A) järgnevalt: "Sellest hoolimata, et hetiit tunnustas, et ta (Assüüria kuningas) vallutas Mitannist allesjäänud alad - selles tekstis nimetatud kui Hurri ning tituleeris ennast nüüd suurkuningaks, väljendas Hetiidi kuningas oma meelepaha sellise asjade käigu suhtes, keeldudes pöördumast tema poole sõnaga "vend", nagu see oli tavaks võrdsete valitsejate vahel. Viide "Amanuse mäe nägemisele" võib tähendada assüürlase hooplemist, et tema väed tungisid nii kaugele loodesse, või väljapakutud kahe suurkuninga kohtumist kohas, mis oli endiselt hetiitide territoorium.“66

Aššuruballit I ja eriti Adadnarari I, Salmanassar I ja Tukultī-Ninurta I valitsemisaeg (u 1365-1207 eKr) oli väga tähtis periood Assüüria ajaloos. Just siis leidis aset Assüüria hegemoonia kehtestamine Põhja-Mesopotaamia üle, just siis rajati propaganda-aparaat ja võeti kasutusele väga auahne titulatuur ning uus administratiivne süsteem ja valitsemismeetodid, mis kõik tulid kasuks Uus-Assüüria impeeriumi kehtestamisele 9. sajandil eKr. Nii

62 Hagenbuchner, Die Korrespondenz der Hethiter, 260-262.

63 Mitanni ehk Hanigalbati kuningas.

64 Ammana ehk Amanuse mäed asuvad Lõuna-Türgi aladel (türgi k Nur Dağları või Amanos Dağları).

65 Beckman, Hittite diplomatic texts, 24A (Letter from Urhi-Teshshup(?) of Hatti to Adad-nirari I of Assyria), 147; vt ka Hagenbuchner, Die Korrespondenz der Hethiter, 260-262; Otten, "Korrespondenz mit Tukulti-Ninurta I. aus Boğazköy", 67.

66 Beckman, Hittite diplomatic texts, 147. 
näiteks mängisid Hanigalbatis asuvad piirkonnad assüürlaste jaoks mitte ainult majanduslikult tähtsat rolli, vaid olid ka geopoliitiliselt olulised. ${ }^{67}$ Tõestatud faktiks võib pidada seda, et Salmanassari agressiivne vallutuspoliitika Põhja-Süürias järgis kindlaid geopoliitilisi sihtmärke: Hanigalbati ja teiste piirkondade vallutamine ning kohaliku administratiivse süsteemi loomine eesotsas Assüüriast määratud asehaldurite jt ametnikega. Niisiis rajas Assüüria oma administratsiooni vallutatud aladele ning lõi puhvertsoone Assüüria põlisala kaitseks tugeva Hetiidi impeeriumi vastu ja võibolla ka platsdarmideks edaspidisteks vallutusteks lääne ning põhja suunas. Kõik see ei saanud meeldida Hetiidi kuningatele Hattušili III-le (1275-50) ja Tuthalija IV-le (1250-20). Olukord muutus veelgi teravamaks TukultīNinurta I ajal, mil Kesk-Assüüria suurriik jõudis oma võimsuse tipule: saavutati oma territoriaalne maksimum, vallutati Babüloonia suurriik ja sellest sai seitsmeks aastaks provints Assüüria impeeriumi kooseisus; jätkati Põhja-Mesopotaamia ja Süüria linnriikide ning hõimude alistamist ja vangistati koguni 28800 hetiidi sõjameest (muidugi kui uskuda assüüria raidkirju); Assüürias tekkis kuninga isikukultus ja jumalikustamine, mis väljendus erinevates auahnetes tiitlites ning $\mathrm{mh}$ ka universalistlikes epiteetides, nagu "maailma kuningas", "nelja ilmakaare kuningas", "kõikide inimeste päikesejumal" jne. ${ }^{68}$ Just sel ajal võttis Hetiidi kuningas Tuthalija IV, vastukaaluks Assüüria valitsejale, kasutusele hetiitide jaoks täiesti võõra universalistliku tiitli LUGAL KIŠ ehk šar kiššati, mis tähendas "universumi kuningat" ${ }^{69}$ Miks ta seda tegi? Tuthalija IV eesmärk seisnes Assüüria kuninga võimsuse purustamises ning võimalik, et just sellest lähtuvalt võttis ta taolise tiitli ka endale. ${ }^{70}$ Huvitav on see, et seda tiitlit kandsid Adadnarari I, Salmanassar I ja muidugi Tukultī-Ninurta I. Nüüd tekkis

\footnotetext{
67 Vt Kesk-Assüüria poliitika ja geopoliitika kohta Adadnarari I, Salmnassar I ja Tukultī-Ninurta I ajal Mayer, Politik und Kriegskunst der Assyrer, 192-221.

68 Vt lähemalt Vladimir Sazonov, "Die mittelassyrischen, universalistischen Königstitel und Epitheta Tukultī-Ninurtas I. (1242-1206)", Identities and societies in the ancient East-Mediterranean regions: comparative approaches: Henning Graf Reventlow memorial volume, hrsg. von T. R. Kämmerer, Acta Antiqua Mediterranea et Orientali, Alter Orient und Altes Testament, 390:1 (Münster: Ugarit Verlag, 2011), 235-276.

69 Hatice Gonnet, "La titulature royale hittite au IIe millénaire avant J.-C.", Hethitica III, ed. by Emmanuel Laroche et al. (Louvain: Éditions Peeters, 1979), 24; Mario Liverani, International relations in the Ancient Near East, 1600-110o BC (Basingstoke: Palgrave, 2001), 23; tiitli LUGAL KIŠ kohta vt Vladimir Sazonov, "Akkadi kuningavõim kui arhetüüp", Ajalooline Ajakiri, 3 (2008), 207-208; Stadnikov, Vana Egiptuse kultuurilugu, 132; vt ka M.-J. Seux, "Les titres royaux "šar kiššati" et "šar kibrāt arba'i”", Revue D’Assyriologie et D’Archéologie Orientale, 59 (1965), 1-18; Tohru Maeda, “"King of Kish" in Pre-Sargonic Sumer", Orient, 17 (1981), 1-17.

70 Vt nt Klengel, Geschichte des Hethitischen Reiches, 294.
} 
olukord, mil Lähis-Idas oli koguni kaks "universumi kuningat", assüürlane ja hetiit, kes mõlemad pretendeerisid oikumeenilise hegemooni staatusele. Muidugi ei saanud näiline sõbralikkus kahe valitseja vahel kesta enam kaua, kui seda kunagi üldse oli olnud.

Tundub, et suhted Hetiidi ja Assüüria impeeriumite vahel muutusid üha vaenulikumaks ning juba Salmanassar I ajal leidsid aset sõjalised kokkupõrked või koguni sõda. Ilmselt oli Salmanassar I selles konfliktis edukam, kuna ta mainis oma raidkirjas: "Mina veristasin nagu lambaid hetiitide ja nende liitlaste aramealaste armeed. ${ }^{\text {"71 }}$ Kuid see ei tõesta veel midagi, sest samas pole teada hetiidi allikaid, mis räägiksid taolisest konfliktist. Arvatavasti olid suhted hetiitide ja assüürlaste vahel Tuthalija IV ning Salmanassar I ajal halvad ja hiljemalt Salmanassar I valitsemise lõpuks lausa vaenulikud, kuid tõenäoliselt leidis see suhete halvenemine aset tunduvalt varem. See oleks ka loogiline oletus. Assüüria tõusuga võisid omavahelised suhted küll aktiveeruda (sh kaubandussuhted), sest Assüüria ja Hetiidi impeerium said naabriteks, kuid hetiitidele vaevalt taoline naabrus meeldis. Kahjuks on säilinud selles ajast väga vähe algallikaid vaid kolm-neli raidkirja, kus põgusalt mainitakse konflikte hetiitidega, ning rohkem diplomaatilisi kirju. ${ }^{72}$ Näiteks kirjutab hetitoloog Heinrich Otten kirja KUB III 74 (Bo 8383) ${ }^{73}$ puhul, et "vennalikust" suhtest Hetiidi ja Assüüria kuningate vahel räägitakse hävinud teksti osas. See Otteni hüpotees pole aga mingi tõsine argument. Kui teksti osa on hävinud täielikult, siis ei saa teha ka adekvaatseid oletusi selle sisu kohta ning kahjuks on sellest kirjast võimalik välja lugeda vaid järgmine lõik kirja alguses:

(Vs. (1)) [Jär]gmisel viisil (kõneleb) Minu Päike, Tuthalija, s[uurkuningas, Hatti maa kuningas.] (2) [Tu]kulti-Ninurtale, [suur]kuningale, [Assüüriamaa kuningale, minu vennale, ütle!]/ (3) Kuna [si]na, Tukult[i-Ninurta $\mathrm{x}]$ (4) Mi[na] heasoovlikult [kirjutasin mina] sul[le. X] [...]. (5) [miski] pärast (6) [Sina] samuti järgmisel viisisl $[\mathrm{x}](7){ }^{74}$

Õnneks on kirjas säilinud saatja ja saaja nimed. Siin me näeme, et Tuthalija IV saatis kirja Tukultī-Ninurta I-le, kuid kirja sisu on äärmiselt fragmentaarne ja sellest pole võimalik eriti midagi välja lugeda. Ka paljude teiste

71 RIMA 1, Shalmaneser I A.o.77.1, 184, read 78-80.

72 Raidkirjadest mainiksin: RIMA 1, Shalmaneser I A.o.77.1; RIMA 1, Tukulti-Ninurta I A.o.78.23; RIMA 1, Tukulti-Ninurta I A.o.78.24 ning kirjadest KUB XXIII 92, KUB XXIII 103, KUB III 73, KBo XVIII 24, KBo XVIII 25 ja KUB III 74.

73 Vt lähemalt Hagenbuchner, Die Korrespondenz der Hethiter, 248.

74 Otten, "Korrespondenz mit Tukulti-Ninurta I. aus Boğazköy", 65, vt originaali Hagenbuchner, Die Korrespondenz der Hethiter, 248. 
kirjadega on sama probleem - need on väga fragmentaarselt säilinud ja tihtipeale ei ole teada saatja ega saaja nime ning sageli pole ka sisu loetav.

Näiteks kirjas KUB III $73^{75}$ pole nimetatud ei adressaati (hetiit) ega autorit (assüürlane), ${ }^{76}$ kuid A. A. Nemirovski arvamusel näitab selle teksti sisu, et selle kirja saatja sai olla vaid Tukultī-Ninurta I. ${ }^{77}$ Nemirovski oletus on huvitav, kuid samas võis selle kirja autoriks olla ka Salmanassar I. Saaja oli ilmselt Hetiidi kuningas Tuthalija IV. Natuke parem on olukord kirjaga KUB XXIII 99 (Bo 424), kus Hetiidi kuningas Tuthalija IV pöördub jälle Assüüria kuninga Salmanassari poole: "Järgmisel viisil Tuthalija, suurkuningas, Hatti kuningas, Aššurimaa kuningale, Salmanassarile, minu vennale, räägib".78 Sellele lausele järgnev pole kahjuks taas eriti arusaadav, kuna on säilinud vaid üksikud sõnad ja paar pikemat lauseosa. Kiri KUB XIII $109,{ }^{79}$ mis on adresseeritud Tukultī-Ninurta I-le, on säilinud veelgi halvemini kui kiri KUB XXVI 70. ${ }^{80}$ On olemas veel kiri KUB XXIII 88 (Bo 211 (+) 2199), ${ }^{81}$ mille kirjutas Salmanassar Hetiidi kuningale. See on säilinud paremini, aga on ka siiski suhteliselt fragmentaarne. Seega ei riskiks ma kirjade põhjal üldse mingeid oletusi teha, kuid seda on tehtud paljude mainekate uurijate poolt ning seisukohad on sageli erinevad.

Päris hästi on säilinud kiri KBo XVIII $24,{ }^{82}$ mis saadeti Hetiidi kuninga (Hattušili III või Tuthalija IV) poolt Salmanassar I-le. ${ }^{83}$ Hetiidi kuningas kirjutab Salmanassarile järgmist:

Rs IV (x+1) [. (.)] neli päev[a X] (2') [ja] see )(x) (3') Babülon (Akk.) [...] $\mathrm{x}[\ldots]$ / (4') Sina aga [oled] nagu tormijumal [tugev?]. (5') päikeseülestõusust lähened sa. [Ammana] mäed (6') tegid sa piiriks. Päikeseloojangule lähened sa. ( 7 ') Linnu, mis olid Šuppiluliuma relvade poolt vallutatud (ja) (8') mis on jumalate tribuut, neid ( $9^{\prime}$ ) oled sa ülevõtnud. (See on see), millest sa mulle (10') alati uuesti kirjutad. / (11') Kuna sina [mul]le [aga] järgmisel viisil kirjutanud oled: "Ühte (12) ustavat meest saada. Ja (13') ta peab Malitija üle kontrollima. Kui (14') minu linnad on minema

75 Hagenbuchner, Die Korrespondenz der Hethiter, 275-277.

76 Ibid., 276.

77 Nemirovskiŭ, "K istorii khetto-assiriŭskikh otnosheniŭ v kontse XIII - nachale XII v. do n.é.", 3.

78 Otten, "Korrespondenz mit Tukulti-Ninurta I. aus Boğazköy", 65.

79 Ibid., 67.

80 Ibid., 67-68.

81 Ibid., 66-67.

82 Hagenbuchner, Die Korrespondenz der Hethiter, 242-245.

83 Ibid., 243. 
läinud, siis [peab Hettimaa kuningas] ja Egiptuse kuningas (16') [... (.)] $\mathrm{x}$ minu/ja piir $\left(17^{\prime}\right)[\mathrm{x}] \mathrm{x}$ on läinud. ${ }^{84}$

Kahjuks on järgmine kiri KBo XVIII $25,{ }^{85}$ mis on Hetiidi kuninga (ilmselt Tuthalija IV) poolt adresseeritud Tukultī-Ninurtale, tugevasti kannatada saanud ja arusaadavad on vaid üksikud laused, mis ei võimalda rekonstrueerida selle kirja sisu.

Nagu näeme, tunnistas Hetiidi kuningas Salmanassari vallutusi ja isegi rohkem - ta kirjutas Salmanassarist kui kuningast, kes "nagu tormijumal” läheneb "päikesetõusust” ja "päikeseloojangule”, aga siis on juttu linnadest, mille Hetiidi kuningas Šuppiluliuma I (ilmselt Mitannis ja Põhja-Süürias) vallutas ja mille Salmanassar I nüüd endale võttis. Kas ta vallutas hetiitidele kuuluvaid linnu või linnu, mis kunagi kuulusid hetiitidele ja siis iseseisvusid, me ei tea. Kas see tähendaks siis, et hetiidid ja assüürlased võisid omavahel sõdida juba Salmanassar I ajal?

Siiski annab meile üks huvitav dokument võimaluse rekonstrueerida sündmusi, mis leidsid aset Tuthalija IV ja Assüüria kuninga vahel. Selleks on kuningas "Tuthalija IV edikt Ugariti kuninga Amištamru II vabastamisest osavõtmisest sõjast Assüüria vastu” ${ }^{86}$ See edikt tõestab, et Tuthalija IV ajal olid hetiidid sõjas Assüüriaga. Kuid millal täpselt ja kaua see kestis, pole teada. Probleemseks asjaoluks on ka see, et Tuthalija IV valitsemise alguses (tuli võimule u 1250) oli veel elus Salmanassar I, kes suri 1244., 1242. või 1241. aastal, ja alles siis (ajavahemikul 1243-40) tuli võimule Tukultī-Ninurta I. Tuthalija IV pöördub ediktis oma vasalli Ugariti kuninga Ammištamru II poole niimoodi:

$\$ 1$, read 1-16. Ini-Tešupi, Karkemiši kuninga [juuresolekul], [Sahurunuva poja], samuti Karkemiši kuninga, Mina, [Minu Päike, Tuthalija], Suurkuningas, Hatti maa kuningas, vabastan [Ammištamrut] Ugariti maa kuningat, [tema jalaväe ja sõidukaarikuid. Kuna sõda] Assüüriaga pole veel lõppenud, [Ugariti maa kuninga] jalaväel ja sõjavankritel pole vaja tulla [mulle appi. Tulevikus] ei süüdistata Ugariti kuningat. Kui sõda Assüüriaga [lõppeb], kui Mina, Minu Päike, saavutan võidu Assüüria kuninga üle, [siis] meie sõlmime teineteisega rahu. Süüdistust ei esitata tema jalaväe ja sõjakaarikute [suhtes], ja isegi hiljem [süüdistust] ei esitata tema vastu. ${ }^{87}$

84 Vt originaali ja sks k tõlget Hagenbuchner, Die Korrespondenz der Hethiter, 243.

85 Ibid., 245-247.

86 Beckman, Hittite diplomatic texts, 37 (Edict of Tudhaliya IV of Hatti realising Ammistamru II of Ugarit from Participation in War against Assyria), 182-183.

87 Ibid., 182-183. 
Seega võib oletada, et sõda assüürlaste ja hetiitide vahel leidis aset Salmanassar I valitsemise lõpus või Tukultī-Ninurta I valitsemise esimese poolel või algas see veel Salmanassar I ajal ja kestis ka Tukultī-Ninurta I valitsemise ajal mõnda aega. Viimane tundub loogiline, samas pole välistatud ka mitu sõjalist konflikti Tuthalija IV ja nende kahe Assüüria kuninga vahel.

On olemas kiri RŠ 34.165, mis leiti Ugariti linnast. See on Assüüria kuninga kiri, mis oli saadetud Ugariti valitsejale, kes oli 14.-13. sajandil eKr Hetiidi suurkuningate vasall. Kirjas on juttu sellest, kuidas Assüüria ja hetiitide "vennalikud" suhted katkesid, kuna nende vahel puhkes sõda Nihria (vb tänapäeva Diyarbakiri kandis) linna pärast. ${ }^{88}$ Nihria $^{89}$ all toimunud lahingus sai Hetiidi kuningas Tuthalija IV assüürlaste käest lüüa. Vähemalt nii väidab Assüüria kuningas, kes selle kirja koostas. Kuid kes see Assüüria kuningas võis olla? Kas Salmanassar I või Tukultī-Ninurta I? Saatja nimest säilisid vaid märgid ... SAG LUGAL KUR... (... SAG, Assüüriamaa kuningas...). ${ }^{90}$ Siin tahan kohe märkida, et uurides kuningate Salmanassar I ja Tukultī-Ninurta I titulatuuri nende raidkirjades, ei leidnud ma et, epiteeti UR.SAG ehk qarrädu $(m)$ (kangelane) oleks kasutatud enne tiitlit šar māt Ǎ̌šur (Assüüria kuningas). Salmanassar I puhul algas seal, kus ta kasutas tiitlit "Assüüria kuningas", titulatuur tavaliselt järgmiselt: Šulmanu-ašared šar kiššati šarru dannu šar māt A ššur. ${ }^{91}$ See tähendab tõlkes: "Salmanassar, universumi kuningas, võimas kuningas, Assüüriamaa kuningas." Tukultī-Ninurta I titulatuuris me ka taolist epiteeti ei näe. ${ }^{92}$ Kirjades kasutati muidugi tiitlit UR.SAG rohkem, aga ikkagi mitte enne kuninga ametliku tiitlit kujul "X maa kuningas". Näitena toon hetiidi kuninga Šuppiluliuma I tiitli ühe teksti algusest:

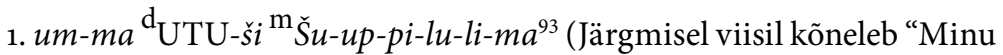
Päike"”, Šuppiluliuma),

\footnotetext{
88 Vt Nemirovskiı̆, " $\mathrm{K}$ istorii khetto-assiriĭskikh otnosheniĭ v kontse XIII - nachale XII v. do n.é", 5-7.

89 Nihria ja Isuva kohta vt nt A. V. Kosyan, "Politicheskie protsessȳ v doline verkhnego Evrata v XV-XIII vv. do n.é.", Édubba vechna i postoyanna. Materialy konferentsii, posvyashchennoĭ 9o-letiyu so dnya rozhdeniya Igorya Mikhaŭlovicha D'yakonova (SanktPeterburg: Izdatel'stvo Gosudrastvennogo Érmitazha, 2005), 149; Bryce, The kingdom of the Hittites, 377; Isuva või Išuwa, mis asus Eufrati ülemvoolust idas, oli veel Tuthalija IV ajal hetiitide käes, vt Klengel, Geschichte des Hethitischen Reiches, 295; Nihria asus H. Klengeli arvamusel ülemises Haburi regioonis Ülem-Mesopotaamias, ibid.

90 Nemirovskiŭ, "K istorii khetto-assiriǐskikh otnosheniǔ v kontse XIII - nachale XII v. do n.é.", 6.

91 RIMA 1, Shalmaneser I A.0.77.6, 186, read 1-3.

92 Vt Sazonov, Die Königstitel und -epitheta, 96-148.

93 Kuninga nimi on kirjutatud valesti, peaks olema kiilkirjas Šu-up-pi-lu-li-u-ma.
} 
2. LUGAL GAL LUGAL KUR ha-at- $t i \mathrm{UR}^{\mathrm{S}} \mathrm{SAG}^{94}$ (suurkuningas, Hatti maa kuningas, kangelane).

Samas võib märk SAG osade uurijate arvates kuuluda Salmanassari nimesse (Nemirovksi hüpotees), kuna Salmanassari nimi sisaldab SAG märki (originaalis kirjutati ta nime kui šùl-ma-nu-SAG ja seda loetakse akkadi keeles kui Šulmanu-ašared); teise arvamuse kohaselt võib see kiilkirja märk SAG olla hoopis epiteedi UR.SAG teine osa, mis tähendas "kangelane" ja mis akkadi keeles kõlas kui qarrādu. ${ }^{95}$ Samas arvab T. Bryce, et lahingus osalejateks olid Tukultī-Ninurta I ja Tuthalija IV. ${ }^{96}$ Nagu Nemirovski väidab, ongi enamik uurijaid arvamusel, et tegemist on Tukultī-Ninurta I-ga, aga mingeid konkreetseid argumente selle oletuse kasuks neil pole. ${ }^{97}$ Seega kaldub ka siinkirjutaja arvama, et tegemist võis olla Salmanassar I-ga, kuna märk SAG on tema nimes vähemalt olemas. ${ }^{98}$

Niisiis, Nihria juures said kokku Assüüria ja Hetiidi armeed. Hetiidi kuningas Tuthalija IV sai lüüa ja oli häbistatud. Horst Klengeli arvates oli Nihrias lüüasaanud kuningas Tuthalija IV, aga see võis olla ka printsina tulevane kuningas Šuppiluliuma II. ${ }^{99}$ Muidugi ei saa välistada ka Arnuvanda III-t, kes valitses Tuthalija IV ja Šuppiluliuma II vahel.

Selles, et assüürlased võitsid Nihria lahingu, pole ilmselt suurt kahtlust, kuna on säilinud üks hetiidi tekst KBo IV 14. See on Hetiidi kuninga (nimi pole säilinud, aga ilmselt see oli see sama Tuthalija IV) pöördumine oma vasalli poole (nimi pole samuti säilinud) seletusega, mis on toimunud hetiidi-assüüria konfliktis ning kuidas vasall peaks käituma. Tekstis on vihjeid kaotusele, mis tabas hetiite lahingus Nihria juures. ${ }^{100}$

Paljud uurijad esitavad siiski küsimuse, millal see nn "vendlus" hetiitide ja assüürlaste vahel lõppes. Assüürioloog Hannes Galter oletusel võisid suhted hetiitide ja assüürlaste vahel halveneda juba Tukultī-Ninurta I valitsemise alguses. ${ }^{101}$ Ta tsiteerib kahte Tukultī-Ninurta I raidkirja, mis

94 Jehad Aboud, Die Rolle des Königs und seiner Familie nach den Texten von Ugarit, Forschungen zur Anthropologie und Religionsgeschichte, 27 (Münster: Ugarit-Verlag, 1994), 48, leping RS 17.277, read 1-2.

95 Nemirovskiı̆, "K istorii khetto-assiriǔskikh otnosheniı̌ v kontse XIII - nachale XII v. do n.é.", 6.

96 Bryce, The kingdom of the Hittites, 317.

97 Nemirovskiŭ, "K istorii khetto-assiriǔskikh otnosheniǐ v kontse XIII - nachale XII v. do n.é.", 6.

98 Ibid., 6.

99 Klengel, Geschichte des Hethitischen Reiches, 296.

100 Nemirovskiĭ, "K istorii khetto-assiriǐskikh otnosheniǐ v kontse XIII - nachale XII v. do n.é.", 6.

101 Galter, "28.80o Hethiter", 217. 
on oma sisult väga sarnased (A.0.78.23 ja A.0.78.24) ja kus on juttu 28800 vangistatud hetiide sõjamehe deporteerimisest Assüüriasse:

Minu valitsemise alguses ( $\mathrm{ja}$ ) minu esimesel valitsemisaastal deporteerisin ma 28800 hetiidi sõjameest sealpoolse Eufrati jõe kaldalt ning tõin neid oma kuningriiki. ${ }^{102}$

Seega võib oletada, et Tukultī-Ninurta I esimeseks valitsusaastaks oli sõjaline kampaania Põhja-Süürias ja Põhja-Mesopotaamias juba lõppenud. Kuid siiski on need kaks raidkirja, kus mainitakse 28800 hetiidi vangistamist ja nende viimist Assüüriasse, uurijate jaoks suur mõistatus. Kõik muud varasemad Tukultī-Ninūrta I raidkirjad algavad Kutu ja Ukumeni vallutamisega ning sõjategevusest hetiitide vastu juttu pole. Seda mainitaksegi alles neis kahes raidkirjas, kus on mh ära nimetatud ka TukultīNinurta I uue residentsi Kar-Tukultī-Ninurta linna rajamist. Nemirovski arvates ei saanud Tukultī-Ninurta teha vallutusi Eufrati jõe taga, sest ligipääs sinna tal sellel hetkel veel puudus, alguses pidi ta vallutama Alzi ja Hanigalbati territooriumid. ${ }^{103}$

Aga kuidas seletada neid raidkirju? Kas Tukultī-Ninurta I sõjaretk Eufrati taha tema valitsemise alguses leidis aset või mitte? Võib ju oletada, et see vastab tõele ning sellel retkel ta vangistas ka hetiite, kuid alguses ta seda mingitel põhjustel ei maininud ja otsustas sellest rääkida alles hiljem, kui need põhjused kadusid. Ja me ju teame, et juba Salmanassar I oli Eufrati piirkonnas aktiivne ja ilmselt sõdis hetiitidega. Hannes D. Gater ja B. Cifola on arvamusel, et 28800 hetiidi küüditamise väide oli vaid propagandistlik fiktsioon. ${ }^{104} \mathrm{~A}$. Harraki ${ }^{105}$ järgi polnud nende 28800 hetiidi sõjamehe deporteerimine Tukultī-Ninurta I valitsemise alguses võimalik, kuna seda ei maini ükski administratiivne dokument. Samas on nimetatud deporteerituid Katmuhist, Alzist, Amadanist, Purulumzist, Nairist. Aga kas pole võimalik, et vajalikke administratiivseid dokumente pole lihtsalt veel avastatud? Siinkirjutaja arvates on väga tõenäoline, et TukultīNinurta I deporteeris hetiite ja ei näe põhjust selles kahelda.

Käesoleva artikli autori hinnangul puudub kõikides nendes ülaltoodud hüpoteesides teatud loogika ja need ei seleta paljusid küsimusi, mis kohe tekivad. Näiteks: milleks oli vaja Tukultī-Ninurtal I luua taoline fiktsiooni

102 RIMA 1, A.0.78.23, 272, read 27-30; RIMA 1, A.0.78.24, 275, read 23-25.

103 Nemirovskiü, "K istorii khetto-assiriı̌skikh otnosheniǔ v kontse XIII - nachale XII v. do h.é.", 4.

104 Galter, "28.80o Hethiter", 233; Cifola, Analysis of variants in the Assyrian royal titulary, 48.

105 Harrak, Assyria und Hanigalbat, 237-241. 
sellest, et ta vangistas 28800 hetiiti või Hetiidi impeeriumi alamaid? Mis eesmärgiga? Kui oletada, et Tukultī-Ninurta I siiski deporteeris ned hetiidid, aga alguses seda ei maininud ja otsustas seda teha alles hiljem, siis pole arusaadav, miks Tukultī-Ninurta I, kes vallutas Babüloonia suurriigi, mis oli 15. ja 14. sajanditel eKr valitsevaks jõuks praktiliselt terves Mesopotaamias, hakkas mingil hetkel arvama, et üks sõjaline ja võib-olla teisejärguline konflikt hetiitidega on tähtsam, kui näiteks võimsa Babüloonia suurriigi vallutamine? Raidkirjadest on ju teada, et pärast Babüloonia vallutamist uhkustab Tukultī-Ninurta I mitmeski raidkirjas kahtlemata oma kõige suurema võiduga ning võtab koguni kasutusele sellised Babüloonia valitsejatele kuuluvad tiitlid nagu šar māt Karduniaš (Karduniaše kuningas), šar mät Šumeri u Akkadî (Sumeri ja Akkadi kuningas), šar Sippar u Bābili (Sippari ja Babüloni kuningas), šar māt Tilmun u Meluhhi (Tilmuni ja Meluhha kuningas) jne. ${ }^{106}$

Kuid pärast hetiitide vangistamist ei võta ta ühtegi uut tiitlit ning ka Hetiidi impeerium on säilinud täies mahus. Pole ka teada, palju assüürlasi selles sõjalises konfliktis hetiitidega surma sai ja kes selle konflikti tegelikult võitis. Ning see arv 28800 võib olla muidugi tugevasti liialdatud. Juba Tukultī-Ninurta isa Salmanassar I mainis ühes oma raidkirjas, et vangistas ja deporteeris 14400 meest Hanigalbatist, ${ }^{107}$ Huvitava paralleeli siinkohal toob W. Mayer, märkides, et Tukultī-Ninurta I poolt vangivõetute arv on täpselt kaks korda suurem. ${ }^{108}$ Seega ilmselt üritaski Tukultî-Ninurta I näidata, et ta on kaks korda parem ja võimsam mees kui oli ta isa. Ka sellise hulga meeste deporteerimine üle Eufrati jõe oleks Tukultī-Ninurta I jaoks olnud tolle aja logistilisi olusid asrvestades päris keerukas ettevõtmine. Nii et vaevalt küll, et see arv nii suur oli. Vangistatud hetiite võis olla vaid mõni tuhat, kuid propaganda eesmärgil võisid assüürlased arvu suurendada 28 80o-ni.

Teine hüpotees (Galter, Cifola), mis väidab, et Tukultī-Ninurta retk hetiitide vastu oli täielik väljamõeldis, ei tugine aga ühelegi tõsisele faktile. Samahästi võiks oletada, et kõik, mis on Tukultī-Ninurta raidkirjades kirjas, on fiktsioon, ja et ta ei vallutanudki Põhja-Mesopotaamia alasid ega ka Babülooniat, kuid selles ei kahtle mitte keegi. Samas on just need kohad raidkirjades, kus Tukulti-Ninurta mainib hetiitide vangistamist, väga lakoonilised ja suhteliselt tagasihoidlikud, võrreldes teiste TukultīNinurta vägitegudega.

Hüpotees selle kohta, et assüürlaste ja hetiitide suhted olid TukultīNinurta I valitsemise esimestel aastatel või koguni tema valitsemise

106 Tukultī-Ninurta I titulatuuri kohta vt Sazonov, Die Königstitel und -epitheta, 96-148.

107 RIMA 1, Shalmaneser I A.0.77.1, 184, read 78-80.

108 Mayer, Politik und Kriegskunst der Assyrer, 210. 
keskpaigani sõbralikud, ei leia samuti mingit tõestust. Ilmselt olid suhted hetiitidega pingelised juba enne Salmanassari I surma, sest on ju teada, et oma valitsemise alguses sõdis Salmanassar Hanigalbatiga, kelle liitlasteks olid hetiidid ja aramealased, ja et ta tappis jõhkralt hetiite. Seda mainib ta ka ise oma raidkirjas. Ka "sõbralikud" kirjad, kus Tuthalija IV ja Salmanassar I nimetasid teineteist "vennaks", pole tõestuseks, sest see oli pigem viisakusvorm, nii pöördusid üksteise poole muistses Lähis-Idas kõik võrdsed valitsejad, kes tihtipeale olid omavahel isegi verivaenlased. Ka tuntud kiri RŠ 34.165 , mis oli adresseeritud Ugariti valitsejale ja kus oli juttu assüüria-hetiidi sõjast, oli nähtavasti koostatud Salmanassar I (nagu pakub seda Nemirovski), mitte Tukulti-Ninurta I poolt. ${ }^{109}$

Tõsi, säilinud on hulgaliselt dokumente assüürlastele kuuluvast DurKatlimmust ja teistest kohtadest, mis näitavad, et assüürlaste, Hanigalbati ja hetiitide suhted võisid olla mingil ajal rahulikud. Kuid kaua selline "rahulik periood" võis kesta?

Rahumeelsed tunduvad olevat olnud assüurlaste suhted hetiitidele kuuluva Karkemišiga. Näiteks räägib sellest üks kiri (BATSH 4 No $\left.6^{10}\right)$, kus on mainitud, et Karkemiši kuningas kaubitses Dur-Katlimmuga ja Karkemiši kaupmehed võisid reisida Hanigalbatis rahulikult. Aga kui kaua see võimalik rahu Karkemišiga kestis, pole teada. Samas, Karkemiši valitseja, kes oli hetiidi kuninga vasall, võis olla mingil ajal n-ö assüüriasõbralik ja mitte tunnistada Hetiidi kuninga ülemvõimu. ${ }^{111}$ On ju teada, et strateegiliselt tähtis ja Põhja-Süürias domineeriv Karkemiši kuningriik oli alati hetiitide ja assüürlaste tüliõun ning mõlema suur ihaldusobjekt.

Kuid mis siis toimus Tukultī-Ninurta I valitsemise teisel perioodil? Oma valitsemise algul oli Tukultî-Ninurta I oletatavasti väga edukas vallutaja. Ta vallutas Nairi piirkonna põhjas, vangistas rohkelt Hetiidi impeeriumi sõjamehi, vallutas osa Hanigalbatist ja terve Babüloonia, tungis Elamisse ja purustas selle. Kuid mis toimus alates 1220. aastatest? Kas siis oli olukord Assüüria jaoks endiselt nii soodne kui 1240.-30. aastatel? Ja kas impeerium oli jätkuvalt stabiilne ka näiteks aastal 1216 või $1209 \mathrm{eKr}$ ?

\footnotetext{
109 Nemirovskiŭ, "K istorii khetto-assiriı̌skikh otnosheniǔ v kontse XIII - nachale XII v. do n.é.", 6, 7 .

110 Eva Christiane Cancik-Kirschbaum, Die Mittelassyrischen Briefe aus Tall Šêh Hamad Beitrage der Asugrabung Tall Šēh Hamad / Dūr-Katlimmu (BATSH), Band 4, Texte 1, hrsg. von Hartmut Kühne, As'ad Mahmoud und Wolfagnag Röllig (Berlin: Dietrich Reimer Verlag, 1996), 117-122.

111 Nemirovski1̌, "K istorii khetto-assiriı̌skikh otnosheniǔ v kontse XIII - nachale XII v. do n.é.", 8-10.
} 
Vaatame korraks, mis toimus samal ajal järsku alla käima hakanud Hetiidi impeeriumis 1220.-10. aasta paiku. Pärast Tuthalija IV surma u 1220. aastal pääses võimule tema poeg Arnuvanda III ning ilmselt sellest ajast on pärit kuninga Arnuvanda leping Ismerikkaga (KUB XXVI 41+ KUB XXIII $68+$ ABoT 58 (CTH 133)). ${ }^{12}$ Selles dokumendis mainib Arnuvanda tervet hulka territooriume, mida ta väidetavasti Hanigalbatis kontrollis. Kui see tegelikkuses nii oligi, siis see näitab hoopis seda, et suurt osa Hanigalbatist valdasid tollal hoopis hetiidid, mitte assüürlased. Samas on pakutud välja hüpotees, et tegemist pole kuningas Arnuvanda III, vaid koguni Arnuvanda I-ga, kes valitses 15. sajandil eKr, kuid selle dateeringu kasuks pole argumente. On teada, et 15. sajandil oli Mitanni veel olemas ja lausa väga võimas suurriik ning Arnuvanda I, kelle ajal Hetiidi suurriik oli nõrgestatud, ei saanud kuidagi kontrollida tollal Mitanni impeeriumi põlisalasid. ${ }^{113}$ Seega on Arnuvanda I lepingu osapoolena välistatud.

On olemas veel üks dokument KBo XVIII $25,{ }^{114}$ mille tugevasti kahjustada saanud tekstist võib lugeda, et Tukultī-Ninurta I andis mingid linnad Karkemiši kuningale. Albertine Hagenbuchner oletab, et selle teksti autor oli koguni Hetiidi kuningas Šuppiluliuma II (Arnuvanda III järeltulija) ja adressaadiks oli hoopis Tukultī-Ninurta I poeg kuningas Aššur-nadin-apli. ${ }^{115}$

Aga huvitav on see, et Assüüria kuningas (ilmselt Aššur-nadin-apli, aga võimalik et juba Tukultī-Ninurta I) loobus mingitest Põhja-Mesopotaamia linnadest Hetiidi valitseja kasuks. Võib-olla oli see samm Hetiidi-Assüüria sõpruse raames, aga ei saa välistada, et Hetiidi valitseja võttis revanši ja purustas assüürlased mingis sõjalises konfliktis. Või siis nõrgenes Assüüria niivõrd, et loovutas need alad hetiitidele, kellel tegelikkuses läks tollal üsna kehvasti. Tundub, et just nii see oligi, sama meelt on ka Nemirovski. ${ }^{116}$ On vähe tõenäoline, et Hetiidi-Assüüria rivaalitsemise ajal muutus Assüüria kuningas nii lahkeks, et kinkis hetiitidele terve rea linnu ja territooriume. On ju teada, et sel ajal läks Tukultî-Ninurta I ilmselt tunduvalt kehvemini kui oma valitsusaja alguses.

Eksisteerib ka Hetiidi kuninga leping Küprosega (KBo XII 39), milles on muu hulgas mainitud Assüüria kuningat, Hetiidi kuninga suuri saavutusi ja juttu on ühest Hetiidi kuninga edust assüürlaste üle - tegu võib olla

112 Kahjuks pole teada, kus see Ismerikka asus.

113 Nemirovskiü, "K istorii khetto-assiriǐskikh otnosheniĭ v kontse XIII - nachale XII v. do n.é.”, 11-12.

114 Ibid., 12-14.

115 Hagenbuchner, Die Korrespondenz der Hethiter, 246-247.

116 Nemirovskiŭ, "K istorii khetto-assiriǔskikh otnosheniǔ v kontse XIII - nachale XII v. do n.é.", 13 . 
diplomaatilise või koguni sõjalise eduga. See võib olla ka väga tühine ja formaalne edu. Kahjuks on tekst jällegi väga fragmentaarne ${ }^{117}$ ja selle tõlgendamisvõimalusi on väga palju. Nagu märgib A. Nemirovski: "Seal hulgas teoreetilisi mõeldavaid variante võiks olla väga palju: mitte ainult sõjaline võit Assüüria üle või territoriaalne laienemine tema arvelt, kuid ka väikesed diplomaatilised järeleandmised või assüürlaste sõbralikud aktid [...]."118

\section{Kokkuvõte}

Kui 14. sajandi teise poole suhetest Assüüria ja Hetiidi vahel ei tea me peaaegu midagi, siis 13. sajandiga eKr on olukord natuke parem - allikaid on rohkem.

14. sajandi algul Assüüria suurriik alles hakkas välja kujunema ning seetõttu olid esimesed kokkupõrked hetiitidega sõjatandril võimalikud umbes aastal 1300 eKr või hiljem. Võimalik, et juba kuningas Adadnarari I ajal 13. sajandi esimesel veerandil võis olla mingi diplomaatiline vastasseis, konflikt või lausa sõjaline kokkupõrge Hetiidi impeeriumiga. Assüürlased tungisid sel ajal Hanigalbatti, mis oli hetiidi mõjusfääris ja mida hetiidi suurkuningad vaatlesid oma vassalina ja puhvertsoonina Hetiidi impeeriumi ja Assüüria vahel. Kuid allikaid, mis seda tõestaksid, leitud pole.

Suhted assüürlaste ja hetiitide vahel olid 13. sajandil eKr muutumas keerulisteks ja pingelisteks. Eriti ilmnes see kuningas Salmanassar I ajal, mil läbisaamine oli pigem vaenulik. Salmanassaril tekkis ilmselt oma valitsemisaja alguses, kui ta sõdis hurriitide kuningriigi Hanigalbatiga, konflikt ka hetiitidega. Ei saa välistada, et hiljem suhted mõneks ajaks paranesid, kuid sellele tõestus puudub. Seega hüpotees selle kohta, et sõbralikud suhted säilisid kuni Salmanassar I surmani (suri u 1244-41 eKr) ja võibolla isegi Tukultī-Ninurta I valitsemise alguseni, ei tundu sugugi tõenäoline. Ka Nihria lahing assüürlaste ja hetiitide vahel leidis aset arvatavasti Salmanassar I eluajal, mitte Tukultī-Ninurta I ajal, nagu mõned uurijad arvavad. Ilmselt leidis Nihria lahing aset Salmanassar I valitsemisaja lõpus ning selle tõestuseks on ka mõned faktid.

Juba hiljem mainis Salmanassari poeg Tukultī-Ninurta I kahes oma raidkirjas (A.0.78.23 ja A.0.78.24), et oma valitsemise esimesel aastal vangistas ta 28800 hetiidi sõjameest. Tundub, et oma valitsemise alguses oli TukultīNinurta I edukas sõjas hetiitide ja nende liitlaste vastu Põhja-Süürias. Kuid

117 Nemirovskiǔ, "K istorii khetto-assiriǔskikh otnosheniǔ v kontse XIII - nachale XII v. do n.é.", 14-16.

118 Ibid. 
mõned uurijad kahtlevad, kas see sõda üldse toimus ning nad arvavad, et küüditatud hetiitide mainimine Tukultī-Ninurta I poolt on lihtsalt propagandistlik fiktsioon. Selle hüpoteesiga pole käesoleva artikli autor nõus. Samas aga, arv 28800 võib olla liialdatud ja reaalsuses küüditas TukultīNinurta I võib-olla vaid mõni tuhat hetiiti. Tekib ka kahtlus Assüüria armee logistilises võimekuses viia mitmesaja kilomeetri taha selline hulk inimesi. Esimesel eelkristlikul aastatuhandel oli Uus-Assüüria impeerium tõepoolest võimeline küüditama kümneid ja sadu tuhandeid inimesi erinevatest piirkondadest, kuid Uus-Assüüria sõjavägi oli tunduvalt suurem ja mobiilsem. See oli juba professionaalne armee ja logistiline ettevalmistus oli kordades parem, kui see oli Tukultī-Ninurta I ajal.

Siinkirjutaja arvates ei saa välistada, et sõjavahekord Hetiidi impeeriumi ja Assüüria vahel võis alata juba Salmanassar I valitsemise lõpus ning kestis Tukultī-Ninurta I valitsemise alguses edasi. On tõenäoline, et nendes Salmanassari ja Tukultī-Ninurta sõdades kaldus võit assüürlaste poole, kes olid ka mujal edukad vallutajad. Samas ei kinnita seda otseselt ükski allikas. Kahtlemata oli Tukultī-Ninurta I valitsemisaja keskpaigaks Assüüria saavutanud peaaegu domineeriva positsiooni Lähis-Idas: Babüloonia oli vallutatud, Egiptuse hiilgeaeg oli pärast Ramses II surma möödumas ning Hetiidi impeeriumis algas pärast Tuthalija IV surma 1220. aasta paiku juba lõplik loojang, mis kulmineerus selle riigi kokkuvarisemisega 12. sajandi alguses. Samas aga - kui uskuda mõnda hetiidi allikat - suutsid viimased Hetiidi kuningad Arnuvanda III ja Šuppiluliuma II saavutada teatava edu Tukultī-Ninurta I või tema poja üle ning saada Assüürialt tagasi mitu linna Põhja-Mesopotaamias. Samas võib olla tegu ka Hetiidipoolse propagandaga. Kuid tähtis on pidada silmas ka asjaolu, et tegelikult oli olukord Tukultī-Ninurta I valitsemise lõpuks muutunud Assüüria jaoks üsna kehvaks, Babüloonias oli ülestõus ja see iseseisvus Assüüriast, ilmselt algas Assüürias kodusõda ja võimuvõitlus.

Lõpuks Tukulti-Ninurta I kukutati ning tapeti oma kaaskondlaste ja sugulaste poolt 1207 . või 1205. aastal eKr. Hetiitidi impeeriumil läks sel ajal ka päris halvasti ning 13. sajandi lõpus ja 12. sajandi alguses hakkas see lagunema. Umbes 1190.-8o. aastatel eKr tungisid "mererahvad" Hetiidi riigi südamesse ning niigi sisemiselt nõrk ja ebastabiilne impeerium varises kokku. Võimalik, et see andis assüürlastele võimaluse hetiitide rasket olukorda oma huvides ära kasutades hõivata piirkondi, mida nad ihaldasid, aga mida Hetiidi suurkuningate vastuseisu tõttu varem vallutada polnud õnnestunud. 
Hiljem, juba 9.-8. sajandil eKr neelas viimased uus-hetiidi kuningriigid Põhja-Süürias enda alla tõusev Uus-Assüüria impeerium, mis oli 9.-7. sajandil eKr peaaegu ainus suurjõud terves Lähis-Idas.

\section{Lühendid}

CTH Emanuel Laroche, Catalogue des texts hittites, Études et commentaires, 75 (Paris, Klincksieck, 1971).

IBoT Istanbul Arkeoloji Müzelerinde Bulunan Boğazköy Tabletleri(nden Seçme Metinler), I (Istanbul: Maarif Basimevi, 1954).

KBo Keilschrifttexte aus Boghazköi (Leipzig, Berlin).

KUB Keilschrifturkunden aus Boghazköy (Berlin).

\section{ABSTRACT: Hittite-Assyrian relations and military conflicts, 1365- 1180 BCE}

This article addresses the complicated issues of Hittite-Assyrian relations and military conflicts from the second half of Middle Assyrian period (ca. 1365-118o BCE) until the fall of the Hittite Empire (ca. 118o BCE). The article is based on the analysis of Akkadian and Hittite cuneiform texts. We have some historical records (cuneiform texts) like treaties, letters, legal documents, etc., which show quite clearly the relations between the kings of Hatti and Assyria. The key events of these relations are mentioned in Hittite-Assyrian international correspondence (diplomatic letters), royal inscriptions, and annals.

The article aims to reconstruct possible Hittite-Assyrian relations at the end of the Late Bronze Age on the basis of remaining written sources from this period. This is of course only a hypothetical image or mosaic that was proposed by the author; other reconstructions and hypotheses are also possible.

In this article, some issues related to the establishment of the power of the Middle Assyrian kingdom during the fourteenth to thirteenth centuries $\mathrm{BCE}$, and at the beginning of Assyrian expansion into northern Mesopotamian and North Syrian regions. These events caused several Hittite-Assyrian diplomatic crises and military conflicts and even wars between these two superpowers of the Late Bronze Age, during the thirteenth century. 
It seems that Assyrian-Hittite wars and military conflicts had begun already at the beginning of the first decades of the thirteenth century BCE, when Assyrian kings, including Adadnarari I and Salmanassar I, conquered and destroyed the powerful kingdom of Khanigalbat, which belonged to the Hurrians and had been for several years a satellite state of the Hittites. Before this event Khanigalbat was partly conquered by the Hittite king Šuppiluliuma I in the fourteenth century BCE. The aim of this state (it was turned into a vassal state) was to be a zone for protection of the Hittite empire's territories from possible foreign invasions from southern and northern Mesopotamia.

During the thirteenth century, Assyrians destroyed the remains of the kingdom of Khanigalbat (Mitanni), conquered it, and the Middle Assyrian kingdom got a border with the powerful Hittite empire, which controlled Anatolia and North Syria. This became the reason for many diplomatic and military conflicts between these two great powers during the thirteenth century BCE, until the Middle Assyrian kingdom weakened after the death of despotic Assyrian king Tukulti-Ninurta (1242-1206 BCE). At the same time, the weakened Hittite empire collapsed - it was conquered by invaders from the Aegean region, so-called "Sea Peoples". This event took place in ca. $1190-1180$ BCE.

Struggles and conflicts between the Hittite empire and the Middle Assyrian kingdom during the thirteenth century BCE were partly documented (international correspondence, royal inscriptions, etc.), but there are not enough written sources from this period and this is a serious issue for reconstruction of Hittite-Assyrian relations. These relations were not strictly hostile, as we know from records that some of the period's Assyrian and Hittite kings communicated as equal and probably friendly partners. There was also active trade and other relations (diplomatic, dynastic, etc.) between the Hittites and Assyrians.

Keywords: Ancient Near East, Hittite Empire, Assyria, Middle Assyrian kingdom, war, conflict.

Vladimir Sazonov (b. 1979) is an Associate Professor at the Estonian National Defence College and a Senior Researcher at the Centre for Oriental Studies, University of Tartu. ${ }^{*}$

\footnotetext{
* Correspondence: Language Centre of Estonian Defence Forces, Estonian National Defence College, Riia 12, 51013 Tartu, Estonia. E-mail: vladimir.sazonov@ut.ee
} 